\title{
Other Virus Grouping
}

National Cancer Institute

\section{Source}

National Cancer Institute. Other Virus Grouping. NCI Thesaurus. Code C14349.

A non-taxonomic grouping of viruses based on a shared characteristic. 